\title{
Climate Change Impact and Adaptation: Lagoonal Fishing Communities in West Africa
}

\author{
K. Sian Davies-Vollum, Debadayita Raha, and Daniel Koomson
}

\section{Contents}

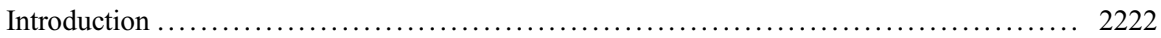

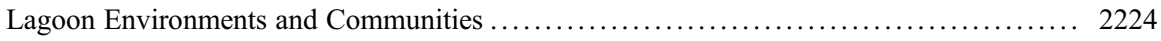

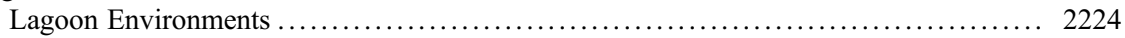

Lagoon Communities ................................................. 2225

Impacts of Climate Change on Lagoons and Lagoon Communities ................... 2226

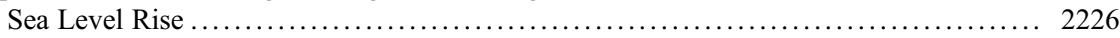

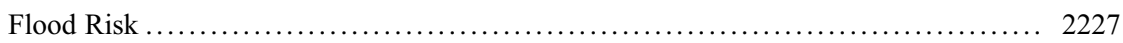

Rainfall and Temperature ........................................... 2227

Vulnerability of and Adaptation to Climate Change in Lagoon Fishing Communities ....... 2228

Community-Level Autonomous Adaptations ................................... 2229

Understanding Vulnerability for Effective Adaptation Planning: Muni Lagoon Case Study ... 2233

Policy Implementation and Participatory Governance ............................ 2235

International Policies and Frameworks Influencing Coastal Governance and Policy .... . 2236

Regional Frameworks and Governance .................................. 2237

National-Level Coastal and Climate Change Policy Mechanisms .................. 2238

Adaptation to Climate Change in Coastal Communities: The Policy Gap ................ 2240

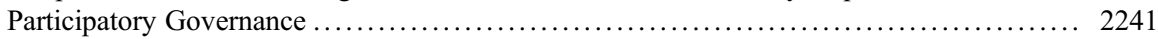

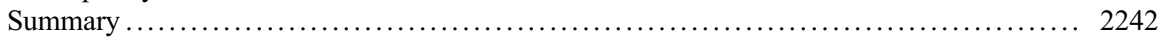

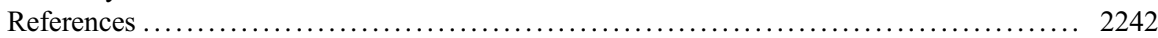

This chapter was previously published non-open access with exclusive rights reserved by the Publisher. It has been changed retrospectively to open access under a CC BY 4.0 license and the copyright holder is "The Author(s)". For further details, please see the license information at the end of the chapter.

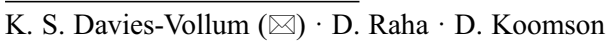

Environmental Sustainability Research Centre, University of Derby, Derby, UK

e-mail: s.davies-vollum@derby.ac.uk; d.raha@derby.ac.uk; d.koomson@derby.ac.uk 


\section{Abstract}

Lagoons are a common feature of the low-lying West African coastline. These lagoons are resource-rich and biodiverse. The small-scale fishing communities, which border them, are dependent on the resources and ecosystem services for their livelihoods and well-being. Climate change has had significant and diverse effects on both the lagoons and their surrounding communities. Sea level rise has caused erosion of the coast and increased the risk of floods. Changes to rainfall patterns have caused shifts in lagoon ecosystems and physical cycles. Of particular relevance to lagoon fishing communities is the fluctuation in quantity and distribution of fish catch that they rely upon for economic livelihood. Understanding the vulnerability of these communities to the effects of climate change is critical to supporting and developing successful adaptations. Using a case study from Ghana, sustainable livelihoods approach (SLA) and vulnerability framework are used to characterize the community vulnerability, giving insight into the temporal and spatial dynamics of vulnerability and how subsections of the community may be identified and prioritized for adaptation interventions. A scalar analysis of the relevant coastal and environmental frameworks and policy to support climate change adaptation in coastal communities reveals the common challenges in implementing adaptation interventions and strategies in the region. A policy gap exists between high level, institutional coastal, and climate directives and implementation of climate adaptations at the local level. That gap might be bridged by a participatory approach that places coastal communities at the center of creating and enacting climate change adaptations.

\section{Keywords}

Lagoon $\cdot$ Vulnerability $\cdot$ Adaptation $\cdot$ Fishing communities

\section{Introduction}

Coastal lagoons, and the wetlands that are often associated with them, are estimated to occupy $13 \%$ of coastlines worldwide (Duck and De Silva 2012). They are found at low-lying, sandy coastlines where they support highly productive ecosystems that provide a wide range of natural functions and ecosystem services to the communities living around them. Lagoons along African coastlines are often home to fishing communities, whose livelihoods are entirely dependent on the resources supplied by them. In West Africa, lagoon communities take advantage of highly productive coastal fisheries that are supported by upwelling along the Gulf of Guinea, which brings nutrients to surface waters. The fishing communities here tend to fish in both shallow coastal waters and coastal lagoons (also known as coastal lakes). Climate change is affecting lagoons and the fishing communities 
that live around them, in multiple interconnected ways. Sea level rise has eroded coastal land and increased the risk of flood. Changes to rainfall and temperature patterns have altered natural lagoon cycles and coastal ecosystems. The resultant changing ocean and lagoon conditions have altered fish catch and fishing practice. The effects of climate change thus have significant implications for the well-being and livelihood of lagoon fishing communities. Understanding how climate change affects lagoon fishing communities is critical to supporting and developing successful adaptations. In this chapter, the impacts of climate change on the lagoons of West Africa, specifically in Cote d'Ivoire, Ghana, Benin, Togo, and Nigeria (Fig. 1), and the fishing communities they support are discussed. How the vulnerability of these communities is characterized, assessed, and connected to climate change is explored. A case study of a fishing community in Ghana is used to exemplify how understanding vulnerability is critical for effective and nuanced community-level adaptation planning. Current international, regional, and national frameworks, governance, and policy to support the creation and implementation of successful adaptation strategies for lagoon communities are presented. The gap between coastal- and climate-related policy and successful implementation of adaptations to climate change in coastal communities is considered and the participatory approach required to bridge that gap presented.

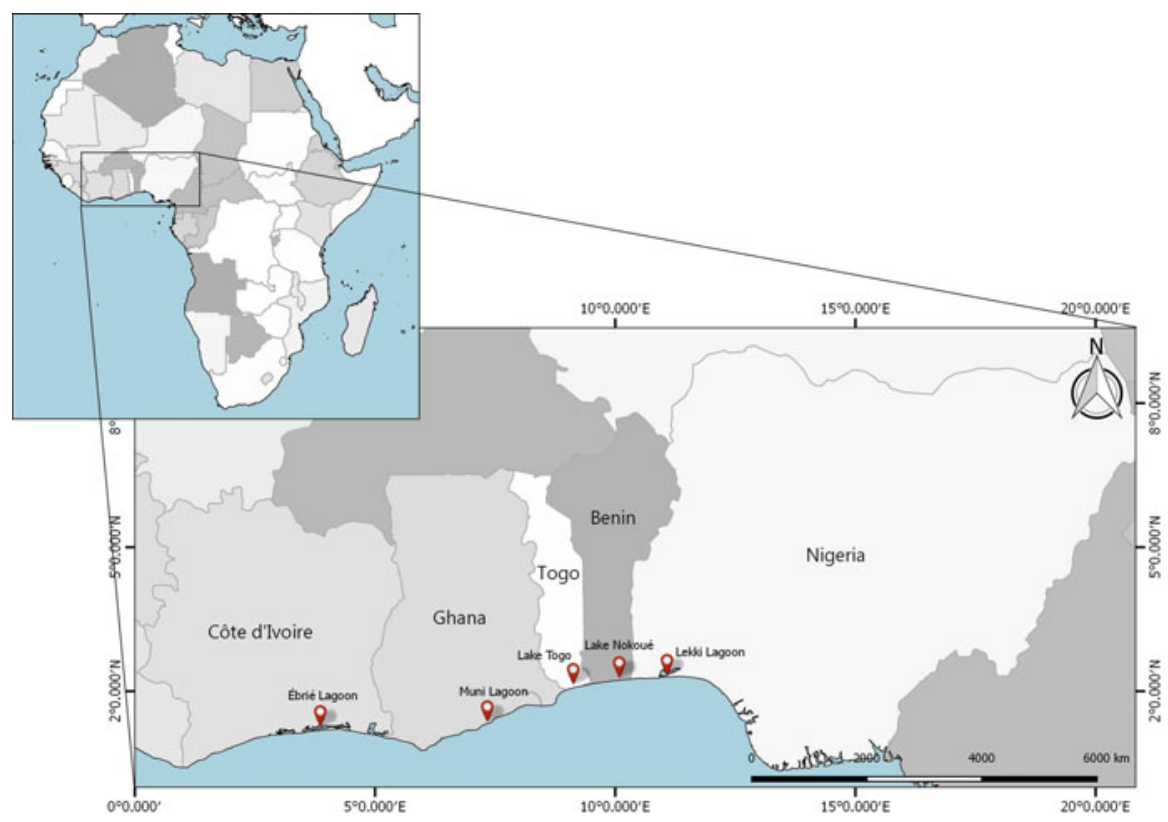

Fig. 1 Map of West African coastal countries with key urban area and lagoons shown 


\section{Lagoon Environments and Communities}

\section{Lagoon Environments}

Lagoons are highly dynamic coastal environments, vulnerable to changes in oceanic and meteorological conditions associated with climate change. They are bodies of coastal water fully or partially separated from the open ocean by a natural barrier. This barrier is of low elevation, often less than two meters above sea level, and consists of sand that is easily eroded and transported. Lagoon barriers can entirely separate the lagoon from the ocean, or they can have one or more breaks, known as breaches or tidal inlets, which connect the lagoon to the ocean. The breaks are important as they act as channels that allow ocean water and biota to enter the lagoon. The barriers can change from whole to breached, and vice versa, in response to variations in weather conditions, hydrological conditions, availability of sediment, and sea level. A seasonal cycle of opening and closing of the sand barriers is common. Natural breaching usually results from overtopping of the barrier from the lagoon when the lagoon is full of freshwater at the end of rainy season. The opening of a lagoon to the ocean allows seawater to flow into the lagoon, resulting in rapid shifts in water temperature, salinity, dissolved oxygen content, and concentration of anthropogenic pollutants. Opening can also alter the tidal amplitude and influence in the lagoon as well as the amount and location of erosion and sediment deposition. Opening can also have an effect on the incidence, amount, and location of flooding. Such fluctuations in the physical environment can create unstable and stressful conditions for lagoon organisms at the species, community, and ecosystem level that can then negatively affect their health and productivity. This in turn influences the availability of natural resources, including fisheries.

Lagoons, or coastal lakes as they are sometimes known in the region, are found at low-lying coastal areas throughout Africa. Along the West African coastline of focus here, there are more than 200 lagoons from Cote d'Ivoire to western Nigeria. This coastline experiences the Guinea Ocean current, which flows from west to east along the west-east trending coastline, creating similar ocean conditions in the region. The lagoons along this coastline vary in size and shape as well as the nature of their connection to the ocean. Two of the largest are Lake Nokoué in Benin and the Lekki Lagoon complex in Nigeria (Fig. 1). Lake Nokoué lagoon covers an area of $120 \mathrm{~km}^{2}$. A former estuary of the Ouémé River, a sand barrier has now enclosed the estuary (Anthony et al. 2002), preventing permanent connection to the sea. The Lekki-Lagos lagoon complex in Nigeria parallels the coastline for approximately $200 \mathrm{~km}$ (Bernacsek et al. 1990) incorporating two separate lagoons: the Lekki and Lagos lagoons. The majority of lagoons, however, in the region are much smaller than these two, with an areal extent from a few to tens of square kilometers.

Lagoons have high biodiversity in tropical and subtropical regions and are often the site of species-rich wetlands. West African lagoons are no exception with high productivity and biodiversity. The key natural resources of these biodiverse lagoons are fisheries and mangroves. According to the USAID, lagoon settings play a key role to fisheries in the area and have been recognized as contributing \$400 million 
annually to the regional economy (USAID 2014). However, the West Africa Regional Fisheries Program (WARFP) indicates that incomes for artisanal (smallscale) fishers have dropped by as much as $40 \%$ over the last decade (The World Bank 2015). This has knock-on effects for the livelihood and well-being of these smallscale fishing (SSF) communities, with the potential to increase their vulnerability to the impacts of climate change. Mangroves are the key lagoon wetland vegetation and provide a variety of ecosystem services: shoreline protection and storm buffering through trapping sediment and dissipating wave energy, regulation of water quality, and provision fish habitats and nurseries (Blankespoor et al. 2014). Through the ecosystem services they provide, mangroves are estimated to contribute approximately 3 billion US dollars annually to the West African economies (Boateng 2018). Despite the importance of mangroves to lagoon communities, they have been decimated due to overexploitation, clearance, and pollution (Boateng 2018; Djihouessi et al. 2016). The impacts of climate change at the coast (sea level rise, changes to temperature, shifts in rainfall patterns, and increased storminess) have further contributed to their demise.

\section{Lagoon Communities}

Coastal towns are Africa's most developed, most densely populated urban areas (State of African Cities 2008), and migration to the coast has been and remains a long-term trend (Ochiewo 2004). The major cities of Abidjan (Cote d'Ivoire), Accra (Ghana), Cotonou (Benin), Lome (Togo), and Lagos (Nigeria) are all situated around one or more lagoons (Fig. 1). Cote d'Ivoire has a coastal population of 8.2 million, which accounts for $36 \%$ of its total population (World Bank 2019). The economic capital and largest urban area of Cote d'Ivoire is Abidjan, which is built around the Ébrié Lagoon. Seventy percent of Ghana's approximately 25 million population (Ghana Embassy 2014) lives in the southern part of the country with maximum population density at the coast. The Korle Lagoon has played a significant role in the development of its capital, Accra. Benin has a short coastline compared to the total area, yet half of its population live in Cotonou, the capital, which is located around Lake (lagoon) Nokou (World Bank 2019). In Togo, the City of Lome lies on the eastern shores of Lake (lagoon) Togo. Lagos, Nigeria's largest city, sits on the Western shores of Lagos Lagoon, part of the Lekki lagoon-barrier system. These lagoons have been an important source of natural resources, including fisheries, supporting the development of the surrounding urban areas. Fishing communities have traditionally lived around the shores and along the lagoon barriers of these highly urbanized areas. Despite the rapid growth and population increase of urban coastal areas, fishing communities still have a strong presence. For example, in Cotonou fishing remains a mainstay of the economy (Dossou and GlehouenouDossou 2007). Lagoons located in less urbanized (rural or peri-urban) areas of the coast are also home to large numbers of small fishing communities. Between $40 \%$ and $45 \%$ of the rural work force of Lagos State of Nigeria engage in SSF, and it is the dominant type of employment (Akanni 2010). At Aby Lagoon in the Cote d'Ivoire, 
fishing is noted as the most important activity for the economy and livelihood of families in the region (Njifonjou et al. 2006), and in Ghana 66.5\% of household livelihood activities in coastal communities are classified as fisheries-based (Evadzi et al. 2018). No matter where they are located, whether in urban or rural areas, these fishing communities are dependent on lagoon and ocean fish stocks for their livelihood and food security. In addition, lagoon fishing communities depend on the myriad ecosystem services that a lagoon system provides such as water resources, flood mitigation, washing and bathing, and wood resources, all of which are subject to the impacts of a changing climate.

\section{Impacts of Climate Change on Lagoons and Lagoon Communities}

\section{Sea Level Rise}

Climate change negatively affects lagoons and the communities they support through sea level rise, changes to rainfall, and increased ocean and air temperatures. During the twentieth century, global average sea level rose by $3.2 \mathrm{~mm} / \mathrm{year}$ (Rahmstorf 2007). During the twenty-first century, rates of SLR are expected to increase with estimates varying greatly from 0.4 meters to 2.5 meters (Hauer et al. 2019). Historic data for SLR in Africa has been limited, and its impacts have been understudied across the continent at both national and sub-national levels (Brown et al. 2011). However, there are an increasing number of studies relating to SLR and its impacts along the coast of West Africa. Coastal management in Ghana has focused on physical processes; thus, most information on SLR and erosion in the region is from here. The average rate of sea level rise over the twentieth century measured at the Takoradi tidal station in western Ghana is $3.34 \mathrm{~mm} /$ year (Sagoe-Addy and Appeaning Addo 2013), and by inference, the rate along this coastline is likely to be similar. Evadzi et al. (2018) noted that on average, sea level in Ghana has risen by about $5.3 \mathrm{~cm}$ over the last 21 years, and SLR accounted for approximately $31 \%$ of the observed annual coastal erosion rate (approximately $2 \mathrm{~m} / \mathrm{year}$ ) in Ghana. The lagoon-barrier coastlines of West Africa are particularly susceptible to erosion associated with SLR because of their low coastal topography and their composition of loose, easily erodible sand. Sea level rise can cause erosion of lagoon barriers, increasing the probability of lagoon opening to the ocean. Average rates of coastal erosion for the coastline between Cote d'Ivoire and Nigeria are around 1.5 meters/ year (World Bank 2019; Wiafe 2010). However, rates of erosion vary greatly along the coast with erosion hotspots recording more rapid shoreline loss. In eastern Ghana, close to the border with Togo, rates of erosion of up to $3.9 \mathrm{~m} / \mathrm{year}$ have been recorded (Boateng 2012), and up to 4 meters/year has been recorded along parts of Benin's coastline (World Bank 2019). High rates of erosion have also been observed near the Lekki lagoon, along Nigeria's lagoon-barrier coast (Danladi et al. 2017). At all these locations, rates of erosion are often exacerbated by the loss of mangroves (Diop and Sherin 2016; Boateng 2018), and in a negative feedback loop, coastlines with high erosion rates often experience increased 
mangrove loss as the root structures of the plant become compromised due to the loss of substrate through erosion. Erosion associated with SLR affects not only natural coastlines, including the lagoon barrier integrity, but also the stability of human structures. This includes dwellings but also fishing-related structures. In Ghana, the loss of fish landing sites in Accra is already recognized (Appeaning-Addo 2014) resulting in the collapse of artisanal fishing.

\section{Flood Risk}

Flood risk for lagoon communities is enhanced by sea level rise, and there are multiple examples of this recorded for the countries considered here. Several Nigerian coastal states are recognized as having high flood risk for an SLR of less than a meter with the barrier lagoon coast of Lagos-Badagry-Seme in the southwestern part of Nigeria noted as particularly vulnerable (Odunga et al. 2014). Also in Nigeria, flooding and associated intrusion of salt water from the ocean have been recorded at the Lekki lagoon-barrier system since the early 1990s (Awoskia and Ibe 1993). The lagoon at Abidjan was highlighted as having a high risk of flooding associated with SLR (Adelekan 2010). In Ghana's central coast, a study of the Muni Lagoon indicated that a 1 meter rise in sea level would almost completely submerge its barrier and inundate the lagoon (Davies-Vollum and West 2015). The poorest communities are those most at risk from flooding, which includes those engaged in SSF. Temporary relocation is the main strategy adopted by members of the communities to adapt to coastal flooding. Some communities also use cheap materials for the construction of their houses as an adaptation to minimize economic loss during inundation (Evadzi et al. 2018). Increased water salinity associated with SLR and inundation inhibits biota in coastal ecosystems, including mangroves, and in a study of coastal wetlands in LEDCs, Blankespoor et al. (2014) estimated that up to $68 \%$ of these would be lost if subject to a $1 \mathrm{~m}$ rise in sea level.

\section{Rainfall and Temperature}

Rainfall projections for the West African coast indicate that during the twenty-first century, precipitation will become extreme with dry seasons becoming drier and wet seasons wetter. Along the West African coast, the major rainy season occurs from approximately March to July, with some geographic variation. Precipitation changes for West Africa include a projected variability in seasonal monsoonal rains (Adeniyi 2016), and there is evidence that the timing and amount of rain that falls during the rainy season have changed (Dossou and Glehouenou-Dossou 2007). In southwestern Nigeria, the rainy season appears to have shifted from March-November to MayOctober (Adelekan and Fregene 2015), and in Ghana, there seems to be less predictability in the onset of monsoonal rains (Koomson et al. 2020). Changes to the amount and timing of precipitation during the rainy seasons can modify the amount of freshwater input to lagoons and disturb the natural cycle of lagoon 
opening. Increased rainfall during the wet season results in more water impounded behind the barrier. This not only causes flooding but also increases the probability of lagoon waters overtopping and/or breaking through the barrier. Rainfall that is more evenly distributed throughout the year results in decreased risk of overtopping and lagoon opening. More evenly distributed rainfall patterns also lead to a more constant input of freshwater, increasing homogeneity of lagoon water conditions throughout the year and stabilizing salinity fluctuations. This in turn affects lagoon ecosystems including fish stocks (Diop and Sherin 2016).

Lagoon and shallow marine ecosystems are also affected by changing water temperatures. A general warming of coastal waters has been noted for the Gulf of Guinea (Druyan 2011). Although there is limited data on the impact of this warming on fisheries in the region, marine species in equatorial regions in general have seen a decline, as they are unable to respond to rapidly increased water temperatures (Hastings et al. 2020). Deoxygenation and acidification of ocean waters are also a consequence of climate change, and both are expected to indirectly reduce maximum fish catch. How fishing communities deal with the physical and ecological changes related to climate change is dependent on their vulnerability to those changes and their ability to adapt to them. Vulnerability and adaptation are inextricably linked, and any discussion about climate change adaptations warrants an overview of the architecture of the vulnerability of lagoon fishing communities.

\section{Vulnerability of and Adaptation to Climate Change in Lagoon Fishing Communities}

Vulnerability can be defined in several different ways in line with different epistemological orientations. However, whether grounded in physical science and human or political ecology, the key concept in vulnerability is the potential for loss or susceptibility to harm. The vulnerability of a community to climate change can be considered as its susceptibility to all the collective changes it experiences. The vulnerability of lagoon fishing communities is related to several multi-scalar factors or causes. The causes of vulnerability in lagoon fishing communities might be categorized into four sources: international, intrinsic, internal, and institutional. International sources refer to global climate and physical environmental change processes such as sea level rise, increase in sea surface temperature, and others, as outlined in the preceding sections. These processes, inter alia, reduce fish catches and revenue (Lam et al. 2016; Dey et al. 2016). Reduced incomes, in neoclassical economic terms, imply reduced purchasing power and so low material well-being (i. e., possession of natural, physical, financial, human resources). Intrinsic sources of vulnerability are those unique to coastal fishing communities and directly linked to their fishing activities. These factors are diverse and include the hazards encountered during fishing (e.g., storms), the seasonality of fish catches, as well as the high unpredictability of making catches. It also includes their high susceptibility to macroeconomic changes. For example, they are forced to accept the market cost of fuel and other necessary resources. 
While intrinsic sources refer to features, which are uniquely associated with the small-scale fishing livelihood itself, internal sources refer to features commonly associated with coastal fishing communities. These include overfishing, gender and income inequality, intra-community conflicts, lack of cooperation, mistrust, and limited livelihood diversification opportunities (Béné 2006). Because artisanal fishing is mostly done in crews and lagoon fishing communities are usually small, trust, camaraderie, and solidarity are essential to sustaining the fishing activity and the community. When these sociocultural factors are missing, the very survival of the fishing livelihood is threatened. Moreover, these internal factors create differentiated experiences of vulnerability within fishing communities (Zacarias 2019; Koomson et al. 2020). Lastly, institutional sources are those related to rural planning, infrastructural development, and encroachment of industrial trawlers. Fishing communities do not usually participate in fisheries planning and management decisionmaking, have little social amenities, and often must deal with encroachment of large trawlers in local fishing waters. This list of vulnerability sources is by no means exhaustive. It is only a sample of the common features of artisanal lagoon fishing communities, which interact in complex ways with the impacts of climate change to make them susceptible to socioeconomic losses.

Whereas vulnerability refers to the susceptibility to harm, adaptation is the process of adjusting to the actual or expected harm and associated impacts, in order to either moderate the harm or exploit beneficial opportunities. The term adaptive capacity is used when considering how capable an individual or community is of adapting to harm or change. The adaptive capacity is based on an individual or a community's available resources that can be drawn on to achieve adaptation. The specific ways in which those combinations of available resources are enacted to moderate harm or exploit beneficial opportunities are then referred to as adaptive strategies. When considering and assessing adaptations and adaptive capacity, there are several critical concepts that should be accounted for. Firstly, it is rooted in the definition of adaptation. An adaptation is an adjustment to moderate actual or potential impacts, not to eliminate or "overcome" them. Secondly, the definition itself makes no value judgment about the legality of the adjustment process or on how the moderation of actual or potential impacts is achieved. In normative terms therefore, any action that has some moderating effect on impacts would qualify as an adaptation strategy. Thirdly, from the definition, adjustments to moderate impacts or benefits from opportunities would not be limited to actions only but also prohibitions. Communities themselves may spontaneously enact adaptations and adaptive strategies. These are referred to as autonomous adaptations.

\section{Community-Level Autonomous Adaptations}

Autonomous adaptations enacted to reduce or moderate harm in SSF communities might also be considered in the context of reducing risk to those communities. Risk reduction strategies that are spontaneously developed by communities whose livelihoods depend on natural resources, such as SSF communities, can be divided into 
five categories: over time (storage), across space and time (mobility), across asset classes (diversification), across households (communal pooling), and market exchange (Agrawal 2008). Communities and individual households may choose to combine and enact any of these strategies to achieve their desired outcomes. This is central to the concept of sustainable rural livelihoods and is important to examine when considering adaptations and adaptive capacity.

One of the earliest discussions on sustainable livelihoods (Chambers and Conway 1992) provided a similar list, which also included reduction of current consumption (stinting), preservation and protection of the asset base for recovery (protection), and making claims on relatives or NGOs (claiming). In a similar discussion on sustainable livelihoods, Scoones (1998) describes two more livelihood strategies: increasing input per unit area (intensification) and expanding the area under production (extensification). These livelihood/adaptation strategy typologies were developed predominately from the study of rural agrarian communities. However, they are also useful for characterizing adaptation strategies reported for commonly reported stressors experienced by fishing communities worldwide, not just in West Africa. These stressors are noted in Table 1. Not all stressors listed are directly related to climate change. Physical stressors like storms and floods and decreasing fish catches are a consequence of climate change. However, encroachment of industrial trawlers into artisanal fishing zone causing competition is not. Competition from trawlers is noted here because of the large impact it has on SSF communities and their vulnerability to climate change. An "experimentation" grouping in the table captures adaptation practices that are less well-established and in an initial learning phase of development (Table 1).

The most common adaptation strategies adopted by SSF communities are intensification strategies (Béné 2006). When fish catches are low, the first and immediate response of SSF communities is to put in more effort either by going further out at sea, spending longer hours at sea, changing fishing gear (equipment) to target fish species that may be relatively more abundant, or increasing the frequency of fishing activities. For example, in a coastal lagoon fishing community situated on the Muni Lagoon in Ghana, the major fishing season, which traditionally lasted from August to April, has been extended by some fishing crews by starting their fishing activities from July to May of the following year. This is largely in response to an erratic rainfall pattern in the major rainy season in southern Ghana. For supplemental incomes, lagoon communities may increase fishing in lagoons and use gears or methods considered illegal. In Benin, Acadjas (a purely ingenious practice of creating a favorable microclimate within a lagoon with sticks and leaves for recruitment of big fish) and médokpokonou (another traditional method which uses nets with fine and tight stitches) are both prohibited, but they are commonly practiced. This is because the former reduces overall fish species richness, and the latter removes small and juvenile fishes (Dossou and Glehouenou-Dossou 2007; Niyonkuru and Lalèyè 2010). The use of mosquito nets in fishing communities has also been observed in Cote d'Ivoire, Ghana, and several other sub-Saharan African countries (Short et al. 2018). This diverts the use of nets away from their role in protecting coastal communities from mosquitoes and negates efforts to reduce 
Table 1 Examples of autonomous adaptation to key stressors of small-scale fishing livelihood in West Africa

\begin{tabular}{|c|c|}
\hline Stressor & Examples of adaptations \\
\hline $\begin{array}{l}\text { Physical (e.g., } \\
\text { storms, floods } \\
\text { and } S L R)^{a}\end{array}$ & $\begin{array}{l}\text { Use of sandbags and rubbish to form defense walls } \\
\text { Change of building materials (from wood and thatch to cement blocks and } \\
\text { galvanized roofing sheets) } \\
\text { Landward relocation of buildings }\end{array}$ \\
\hline $\begin{array}{l}\text { Reduced fish } \\
\text { catch }^{a-g}\end{array}$ & $\begin{array}{l}\text { Intensification strategies } \\
\text { Spending longer times at sea } \\
\text { Use of small meshed nets (e.g., médokpokonou and "wan" practices in } \\
\text { Benin) } \\
\text { Fish trapping (e.g., the Acadja practice in Benin) } \\
\text { Change of gear and fish species harvested } \\
\text { Increased frequency of fishing in lagoons } \\
\text { Extended major fishing season } \\
\text { Extensification strategies } \\
\text { Going further out into the sea } \\
\text { Fishing in neighboring coastal communities during taboo days in own } \\
\text { community (practiced in some beach-seining communities in Ghana) } \\
\text { Temporal migration } \\
\text { Diversification/occupational mobility strategies } \\
\text { Taking wage labor jobs during lean seasons } \\
\text { Adding supplementary livelihoods like livestock rearing } \\
\text { Sand winning (extraction) } \\
\text { Planting, harvesting, and sale of coconut fruits } \\
\text { Storage strategies } \\
\text { Preservation of fish for sale in lean seasons and/or to sell in new and fairer } \\
\text { markets } \\
\text { Reducing household expenditure in order to save money } \\
\text { Borrowing from money lenders } \\
\text { Remittances } \\
\text { Experimentation strategy } \\
\text { Varying the hours within the day when fishing expeditions are made }\end{array}$ \\
\hline $\begin{array}{l}\text { Encroachment } \\
\text { of industrial } \\
\text { trawlers into } \\
\text { artisanal } \\
\text { fishing zone }\end{array}$ & $\begin{array}{l}\text { Experimentation strategy } \\
\text { Studying to precede trawlers or waiting a long while after they have gone }\end{array}$ \\
\hline
\end{tabular}

${ }^{\mathrm{a}}$ Freduah et al. (2018)

${ }^{\mathrm{b}}$ Béné (2006)

${ }^{\mathrm{c}}$ Perry and Sumaila (2007)

${ }^{\mathrm{d}}$ Dossou and Glehouenou-Dossou (2007)

${ }^{\mathrm{e}}$ Niyonkuru and Lalèyè (2010)

fDaudu et al. (2020)

${ }^{\mathrm{g}}$ Adelekan and Fregene (2015)

malaria. Intensified fishing efforts in response to declining catches are the main reasons behind accusations of SSF as being overexploitative and unsustainable.

Adaption studies from Ghana show that SSF communities also extend efforts by going further into the sea, fishing in areas outside those of their own fishing 
communities, or moving temporarily to other towns or even countries to fish (Perry and Sumaila 2007; Freduah et al. 2018). Some small-scale fishers maintain contact with fishers from other communities through mobile phone communication to share information about the location of big catches. The fishers respond quickly by moving to that location to fish for a day or two. It is common among West African coastal fishing communities to have indigenously instituted no-fishing (taboo) days (Adjei and Sika-Bright 2019). By way of extensification, some fishing crews move from their communities on taboo days to fish in nearby communities as a strategy to increase catch and thus their weekly earnings. These strategies thrive on good social networks and camaraderie between communities.

Adaptations that are based on diversification of livelihood in SSF communities involve either taking on additional sources of income or changing and acquiring different types of fishing gears or both. Daudu et al. (2020) have shown that gear and occupational diversification are priority strategies for some fishing communities in Nigeria. Some members of a fishing household may take up wage labor jobs as complementary livelihood sources all year round or during some parts of the year. However, for households that have temporary non-fishing livelihoods, fishing is an activity to which they always return. Few artisanal fishers ever leave fishing permanently. Fishing, for them, is not just a livelihood activity; it is their culture, an important part of their identity and something they take pride in. West African coastal fishing communities do not have a strong tradition of farming as an additional source of income. However, recent increase in demand of specific products has provided opportunities for the diversification of livelihoods into harvesting local products. For example, in Ghana, the rise of demand for coconut fruits in large cities has created opportunity for fishers living in coastal areas to harvest and sell coconuts from coconut trees in their vicinity. Others harvest from trees growing on "no man's lands." This has become an important complementary source of income for fishing communities. In some instances, community members might engage in illegal activities to diversify sources of income. Sand winning (extraction of sand from beach areas) is a prohibited activity in most communities and illegal in accordance with national policy in most West African countries. However, some members of SSF communities are involved with sand winning for income.

Evolution of storage strategies is commonly reported as an autonomous adaptation in lagoon communities along coastal West Africa. Storage strategies have been identified in fishing communities in Cote d'Ivoire (Njifonjou et al. 2006), Ghana (Freduah et al. 2018), and Nigeria (Adelekan and Fregene 2015). Storage strategies are usually in the form of securing household sustenance by processing (commonly by smoking or drying) and storing fish to be sold in the lean fishing seasons, borrowing from credit lenders, and/or saving money during the major fishing seasons. This money-saving strategy differs from conventional money-saving practices that aim at saving disposable income. It is an active and often necessary saving against lean seasons, unexpected periods like stormy conditions, or close fishing seasons. It has also been widely observed that some rural households are cushioned by remittances from household members who have migrated either temporarily or permanently from their original community. While this may be true for some 
communities, it may be a largely missing income stream in other communities. For example, Atti-Mama (1998) reported in a study of nine communities around Lake Nokoue in Benin that more than $95 \%$ of households did not receive any remittances.

In response to the encroachment of large trawlers into local fishing waters, coastal fishing communities have no clear strategy. As this is a longstanding but still evolving problem, identified adaptive strategies are, at best, experimental. This may be more conveniently termed a coping mechanism rather than an adaptive strategy. Some authors have particularly highlighted that adaptation strategies are different from coping strategies noting that the former are permanent and long-term changes in practices, while the later are temporary and short-term changes in livelihood practices (Scoones 1998).

The Muni Lagoon and Akosua Lagoon community are used as a case study to illustrate the importance of understanding the vulnerability of an SSF community when planning adaptations.

\section{Understanding Vulnerability for Effective Adaptation Planning: Muni Lagoon Case Study}

Internal factors can differentiate the experience of vulnerability in fishing communities. This phenomenon presents both challenges and opportunities for effective adaptation planning in fishing communities. A case study of Akosua village, a lagoon fishing community in Winneba, Ghana, demonstrates this (Koomson et al. 2020).

Akosua village is a small migrant fishing community located on the central coast of Ghana on the outskirts of the town of Winneba (Fig. 1). The community is situated on the sandy barrier that separates the Muni Lagoon from the Atlantic Ocean. The lagoon has been well studied as it was designated as a Ramsar (protected wetland) site in 1992 (GEF 1992). The economy of the community is based predominately on beach seining. This is a fishing method that involves the deployment of seine nets into the sea and hauling them back to shore by hand. Beach seining is done mainly by men. The women in the community are the fishmongers, mostly engaged in the processing and selling of fish. In addition to the predominantly fishing-based livelihood, some women engage in petty trading, and some men engage in daily wage labor jobs within the town of Winneba. Farming and livestock rearing are uncommon in the community due to the sandy and saline nature of the land. The poor quality of the land for farming is common to all lagoon communities and limits opportunities for alternative livelihoods. To understand how vulnerability is manifested within the community, the structure of the fishing activity must be appreciated. Fishing crews are typically made up of the "net owner" (i.e., the owner of the boat, outboard motor, and seine net), boat crew (the net owner's permanent employees), and net draggers (casual workers who haul the net to shore). This crew hierarchy delineates households' economic class as profit is typically shared in the ratio 4:2:1 among the net owner, boat crew, and net draggers, respectively. Crews range from about 12 to 35 men depending on the size of boat and net. The major fishing season starts from the end of the major rainy season (July/ 
August) to its beginning (March/April) the following year. The period in between (April-July) is the major rainy season characterized by stormy conditions. Thus, no or very limited fishing activities take place during that part of the year. The community major fishing seasons are considered the "good season" when catches are big and incomes are high and the "bad season" when catches are small and incomes are low. This is purely subjective but reflects the community's perception of their well-being during the year. Besides the interruption of fishing activities and income flows by unpredictable stormy conditions, sudden rainfall is a major problem to fish processing. The major fish processing method used in the community is drying in the open fields (Fig. 2). Unexpected rainfall, therefore, results in losses as the half-dried fish in the open fields deteriorate upon contact with water. Besides this, long periods of dryness cause the surface area of the lagoon to decrease in size and reduce the lagoon's water quality. Changes to the lagoon size and water quality have knock-on detrimental effects on fish productivity and species diversity.

The study integrated the concepts of vulnerability and the capital assets component of the sustainable livelihoods approach (SLA) to understand how the lives and livelihood of the community are impacted by climate variability. Drawing upon the IPCC's definition of vulnerability as a function of the magnitude of climate variation to which a system is exposed (E), its sensitivity (S), and its adaptive capacity (AC), a simple equation that multiplies $\mathrm{E}, \mathrm{S}$, and $\mathrm{AC}$ was used to quantitatively estimate the vulnerability of each household. This is a commonly used methodology according to the Intergovernmental Panel on Climate Change (IPCC 2014). The SLA is a framework designed to identify combinations of livelihood resources, which give people the ability to adopt livelihood strategies that produce their desired outcomes, as well as the institutional processes that mediate their ability to carry out such livelihood strategies within defined policy and ecological and socioeconomic

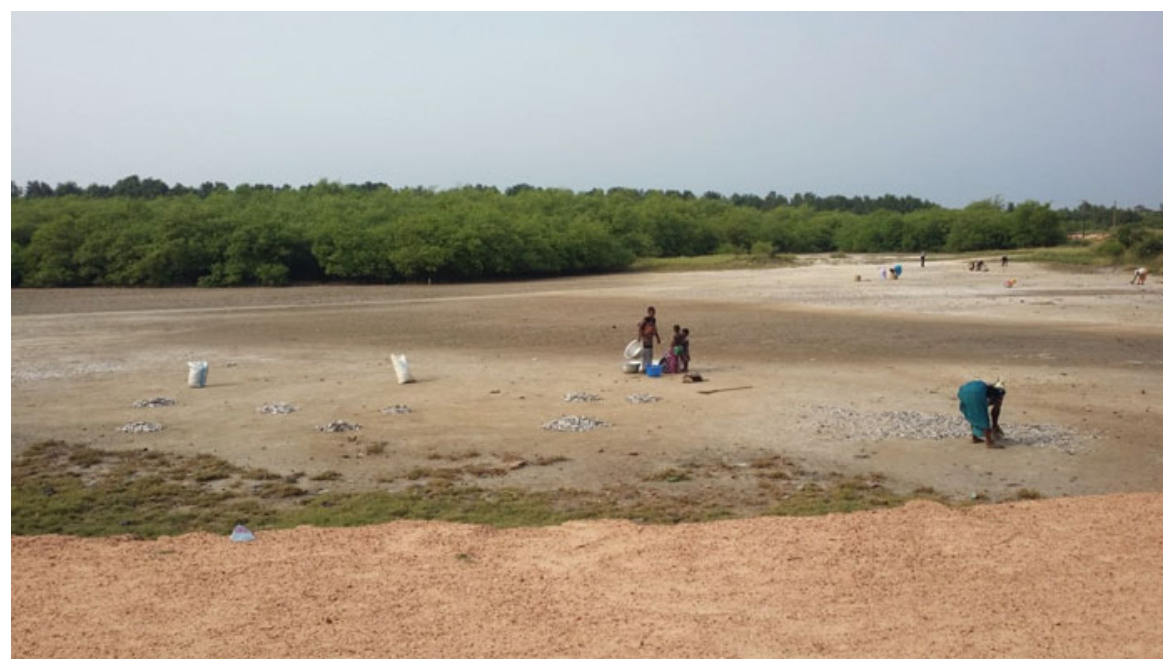

Fig. 2 Drying fish on a dry lagoon bed in Winneba, Ghana. (Photo D. Koomson) 
contexts (Scoones 1998). At the heart of the SLA is the concept that rural communities draw upon and combine five main capital assets (natural, physical, social, human, and financial) to build their livelihoods and respond to shocks. An assessment of the levels of these capital assets and barriers to their access gives insight into what policies are necessary to expand the livelihood platform, thereby improving adaptive capacity and reducing vulnerability (Freduah et al. 2018).

Understanding the experience of vulnerability and autonomous adaptations to climate change in the Akosua community, and the role that internal factors play, has implications for adaptation planning in the community and other communities with similar contexts along the West African coastline. The scale of economic impact that bad seasons have on the household incomes is very important in determining vulnerability. Comparing incomes in good and bad seasons shows that household income drops by about $90 \%$ in a bad season (Koomson et al. 2020). With good seasons becoming rare with increasing climate change, food security is threatened. Vulnerability to impacts is not felt in the same way across the community. It is differentiated depending on the gender and wealth status of a household head. For example, in bad seasons, a household in a lower wealth rank and headed by a woman may be comparably less vulnerable than a household of a higher wealth rank and headed by a man. Thus, the most vulnerable are not necessarily female-led and poorer households, as might be expected. Adaptation planning, such as the introduction of alternative/complementary livelihoods, therefore, must be flexible enough to respond to the cyclical and yet unpredictable nature of bad seasons and prioritize the most vulnerable. Such an intersectional understanding of vulnerability is essential for effective adaptation planning because the factors that are responsible for determining who is more vulnerable in the community differ depending on how households are categorized for study (Koomson et al. 2020). An intersectional understanding means that each household's experience of impact should be understood based on the different social identities that characterize that household. For example, a poor household, headed by a woman who is a migrant, may experience impacts differently from a poor household, headed by a woman who is indigenous to that place. Achieving optimum success in adaptation implementation would require that important nuances in differential vulnerability, as identified through an intersectional lens, be leveraged to prioritize critically vulnerable households. This detailed understanding of vulnerability in SSF communities is key to informing interventions that support successful adaptations to climate change. The development, implementation, and inaction of adaptation intervention strategies to address climate change in SSF communities can be realized on the large scale by embedding concepts of adaptation and adaptive capacity in regional and national coastal governance and policy.

\section{Policy Implementation and Participatory Governance}

Along with the community-level adaptation, there are policy and governance structures that aim to implement sustainable adaptive capacities for SSF communities. Coastal policies create strategies and establish governance processes and 
mechanisms to enable coastal fishing communities to implement adaptations to protect and deal with climate change. Well-informed and wide-ranging coastal policies acknowledge that subsistence and resource-dependent SSF communities are faced with climate change impacts and need to undertake sustainable practices for their livelihood, well-being, and development. There are a number of overarching international frameworks that influence and guide regional and national coastal governance and policy in West Africa. These directly or indirectly inform strategies for and governance of adaptation to climate change in lagoon communities.

\section{International Policies and Frameworks Influencing Coastal Governance and Policy}

At the global level, the Intergovernmental Panel on Climate Change (IPCC), Sustainable Development Goals (SDGs), and Ramsar Convention provide overarching frameworks for considering coastal governance. In addition, the concept of integrated coastal zone management establishes guidance on managing coastlines holistically. The IPCC highlights the need to explicitly address coastal communities in any climate change policy. The SDGs, specifically 1, 6, 7, 12, 14, and 15, draw attention to the threats posed by climate change in coastal communities in countries of the Global South (UN 2015). Sustainable Development Goal 14, "Conserve and sustainably use the oceans, seas and marine resources for sustainable development," is particularly pertinent for the resources, economy, and livelihood of these coastal communities (UN 2015). This is manifested through the vision of the "Blue Economy": the sustainable use of ocean resources for economic growth, improved livelihoods and jobs, and ocean ecosystem health (World Bank 2015). The concept of integrated coastal zone management (ICZM) arose from the Earth Summit (Rio Convention) in 1992. The aim of the ICZM was to enable governments to create national agendas to understand and find solutions to managing the complex and dynamic nature of the coastal environment. The ICZM concept is embedded in the ecosystem approach, a strategy for the integrated management of land, water, and living resources that promotes conservation and sustainable use in an equitable way. Both the ICZM and the ecosystem approach require that management of the coastline incorporates the impact on and implications for coastal communities of resource usage, pollution, livelihoods, and hazards (including climate change). The aim was to merge physical and environmental aspects of coastal management with human needs, with the ultimate benefit of maintaining coastal ecosystems and environments. However, embedding both the ICZM and the ecosystem approach in decision-making and implementation in the Global South, including West Africa, has not proved to be successful, and considerable challenges remain. The International Convention on Wetlands of 1971, otherwise known as the Ramsar Convention, was established as an international cooperation with national action for the conservation and wise use of resources in wetlands (both coastal and inland) of global significance, including coastal lagoons. Of the countries discussed here, Ghana became a member state of the Ramsar Convention in 1988, closely followed by 
Togo (1995) and Cote d'Ivoire (1996). Benin and Nigeria became contracting parties in 2000 and 2001, respectively. The ways in which the Convention mandates are implemented by respective governments differ vastly as the Ramsar Convention gives national governments a broad scope for implementation that relies on effective, dynamic and multilevel processes of implementation (Mauerhofer et al. 2015). The Convention does provide a platform for knowledge transfer as well as management oversight and some level of resources for the protection of specific coastal lagoons.

Along with these international conventions, frameworks, and treaties, there have been regional collaborative initiatives relevant to coastal fishing communities. These regional partnerships include measures to sustainably manage marine and coastal resources, including fish stock and coastal habitats, which help augment the resilience of coastal communities to climate change (FAO 2018).

\section{Regional Frameworks and Governance}

At the regional level, West African countries have undertaken different collaborative initiatives and frameworks related to aspects of coastal management and governance. These include the West Africa Coastal Areas Resilience Investment Project (WACA ResIP), the Guinea Current Large Marine Ecosystem (GCLME) program (GCLME 2006), the Fisheries Committee for the West Central Gulf of Guinea (FCWC), and the West Africa Coastal Areas (WACA) Management Program.

The West African countries of Benin, Cote d'Ivoire, Togo, and Senegal are part of a six-country West Africa Coastal Areas Resilience Investment Project (WACA ResIP) aimed at strengthening coastal communities in West Africa. This program assesses coastal damages in terms of economic impacts, environmental implications, and social effects of changing climate. Since 2005, the joint United Nations Development Programme-Global Environment Facility-United Nations Industrial Development Organization (UNDP-GEF-UNIDO) regional collaboration known as the Guinea Current Large Marine Ecosystem (GCLME) program has existed to reduce poverty and enhance economic development of coastal communities through the provision of country-driven mechanisms to support marine and coastal goods and services. It comprises 16 countries of West Africa, including Cote d'Ivoire, Ghana, Benin, Togo, and Nigeria. The GCLME has its roots in the late 1990s when the ecosystem approach was introduced to assess and manage marine resources in West Africa. It provided a framework to promote the ecosystems approach and broaden the scope of coastal management in the region. It prioritized five aspects of coastal communities and environments: (i) productivity, (ii) fish and fisheries, (iii) pollution and ecosystem health, (iv) socioeconomic conditions, and (v) governance. The GCLME enabled large investments to combat coastal change and implement management strategies for coastal issues in the region. An emphasis was placed on monitoring physical processes and hard engineering solutions with little recognition of lived experience of coastal communities. Coupled with weak assessment and governance and an inadequate understanding of the complexities facing coastal communities, the programs put in place through the GCLME have not been successful. 
The FCWC and WACA have focused on small-scale fishing. Goals of these programs have been to promote sustainable fisheries management, build strong fisher folk associations, support women in fisheries, ensure efficient fisheries value chains, and identify the challenges of overfishing and other competing uses for coastal areas. The Fisheries Committee for the West Central Gulf of Guinea (FCWC) is a regional integration plan for the Food and Agriculture Organization to ensure the "the blue economy" of the region is based on the participation of smallscale fishers in resource management. It was created by the nations of Benin, Ghana, Togo, Nigeria, Liberia, and Cote d'Ivoire to boost the fisheries sector, by ensuring the sustainable management of their fisheries resources for export and small-scale fishing communities. The West Africa Coastal Areas (WACA) Management Program was launched in 2018 by the World Bank. At its center, the WACA provided access to knowledge and technical expertise, made political and financial commitments, and supported a coordinated, regional approach for coastal resilience in West Africa to enhance adaptive capacity of fishing communities. While these multiple regional and international efforts have been well-intentioned, they suffer from some major drawbacks. Multiple initiatives have led to overlapping governance efforts, with complex organizational structures, funding, and implementation processes that have hampered the success of the initiatives. A top-down approach with limited local input and ownership of projects also meant that the long-term success of initiatives was restricted (Wiafe et al. 2013). All of these initiatives and frameworks emphasized management of the coastline and near-shore environments rather than focusing on climate change. The National Adaptation Programme of Action (NAPA) plans do specifically address adaptations to climate change in countries of the Global South and inform climate change policy relevant to coastal environments and communities.

\section{National-Level Coastal and Climate Change Policy Mechanisms}

The National Adaptation Programme of Action (NAPA) is national-level adaptation plan submitted to the United Nations Framework Convention on Climate Change (UNFCCC) secretariat by the least developed member states in 2007 and 2008. These documents outline the threat to individual nations and their planned priority adaptation actions. Development of the Intended Nationally Determined Contributions (INDC) followed, submitted in 2015. The INDC outline the priority adaptation sectors and interventions for a country and run from 2016 to 2030. The National Adaptation Programme of Action (NAPA) for coastal West African countries acknowledged the adverse impacts of climate change on SSF communities, signposting threats to these communities and their livelihoods and creating adaptation plans (Table 2).

The selection of priority adaptation interventions for NAPAs (and INDCs) was based on a multi-criteria analysis that included monetary cost and benefit, potential economic benefits and synergy with other environmental policies, as well as potential contribution to poverty alleviation. While it is noteworthy that SSF communities and their livelihood are quite significantly acknowledged in national policies, none 
Table 2 Climate change adaptation plans for coastal SSF communities across West Africa

\begin{tabular}{l|l}
\hline Country & Stated adaptation plans for SSF communities \\
\hline Ghana $^{\text {a,b }}$ & $\begin{array}{l}\text { Enhance fisheries resource management } \\
\text { Develop alternative sources of livelihoods for fisher folk } \\
\text { Promote fish farming }\end{array}$ \\
\hline Nigeria $^{\mathrm{c}, \mathrm{d}}$ & $\begin{array}{l}\text { Enhance artisanal fisheries and encourage sustainable aquaculture } \\
\text { Encourage the provision of social welfare programs by faith-based and civil society } \\
\text { organizations to address the climate change-induced needs of vulnerable groups }\end{array}$ \\
\hline Togo $^{\mathrm{e}}$ & $\begin{array}{l}\text { Protect the coastal zone } \\
\text { Strengthen infrastructure resistance to climate change in coastal zones } \\
\text { Strengthen community resilience to climate change in the coastal zone }\end{array}$ \\
\hline Benin & $\begin{array}{l}\text { Ensure the protection of the shoreline against the risk of sea level rise } \\
\text { Reduce the vulnerability of human settlements and resources located in the coastal } \\
\text { area to sea level rise } \\
\text { Ensure continuously the protection of marine and lagoon ecosystems }\end{array}$ \\
\hline $\begin{array}{l}\text { Cote } \\
\text { d'Ivoire }\end{array}$ & $\begin{array}{l}\text { All policy documents for this country are in French (official language of the } \\
\text { country) thus not accessible for review purposes }\end{array}$ \\
\hline
\end{tabular}

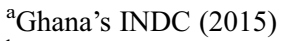

${ }^{\mathrm{b}}$ National Climate Change Adaptation Strategy (2010-2020)

'Nigeria's INDC (2015)

${ }^{\mathrm{d}}$ National Adaptation Strategy and Plan of Action on Climate Change for Nigeria (NASPA-CCN, 2011)

${ }^{\mathrm{e}}$ Togo's INDC (2015)

${ }^{\mathrm{f}}$ Readiness Project for Benin's Intended Nationally Determined Contributions (2018)

of these actions made it into the priority actions for any of the countries, which were mostly focused on agriculture, transportation, energy, and health sectors. The MCA approach is likely responsible for the prioritization of other livelihoods like rural agriculture over SSF fishing. As is widely noted in the SSF literature, the contribution of SSF to national economies, in terms of GDP, is relatively small. Poverty alleviation, food security, and rural economic development are the most significant contributions of SSF. However, it is also acknowledged that in comparison to other rural livelihood activities like farming, SSF has higher exposure and sensitivity to climate change impacts. While the MCA process is not completely described in the reviewed documents, it could be conjectured that if the disproportionately higher vulnerability of SSF communities had been considered and higher weights assigned to poverty alleviation and food security, adaptation interventions for SSF communities would have risen in priority. Countries differed in which aspects of coastal adaptations took precedent (Table 2). While some countries (Ghana and Nigeria) focused on livelihoods of coastal communities by establishing means for improving and enhancing income generations, others such as Benin, Togo, and Cote d'Ivoire concentrated more on hard engineering solutions to protect coastal infrastructure (Table 2). The NAPA were not as wide-ranging or successful as they might have been at addressing coastal adaptations to climate change.

All countries adopted a multi-sectoral approach to adaptation planning and demonstrate an appreciation of the need to connect adaptation planning with the broader national development agenda. However, the multifaceted and complex 
interlinkages between climate change, natural resources, and local development issues that underpin vulnerability of a community, and which are critical to successful adaptation interventions, were not fully appraised as part of the plans. In addition, NAPA implementation required strong cross-sectoral collaboration to realize the planned adaptation interventions, and this was not necessarily in place due to gaps between national policy and local implementation.

\section{Adaptation to Climate Change in Coastal Communities: The Policy Gap}

Institutional arrangements in Africa have conventionally followed a formal, topdown framework. The national and regional policy agreements in Benin, Nigeria, Ghana, Togo, and Cote d'Ivoire aimed at coastal management and enhancing adaptive capacity of coastal communities are managed and implemented by government organizations, often in partnership with nongovernmental organizations. This multi-organizational, top-down approach has resulted in several barriers to the successful implementation of policy-driven climate change adaptation strategies at the coast. Policy deployment through multiple national and nongovernmental agencies can often result in uncoordinated and overlapping strategies resulting in confused implementation at the local level and limited success of adaptation strategies. The current national governance top-down approach allows limited opportunities for local governance. This creates a gap, "the policy gap," between the well-intentioned policy discourse at the national government level and the actual implementation of policy at the village level. The top-down approach also results in failure to understand and address the highly localized and often community-specific conditions required to enact successful climate change adaptations. When multi-institutional governance structures include engagement opportunities for local communities, the success of coastal management plans and adaptation strategies is greatly enhanced. For example, an understanding of specific local environmental conditions and socioeconomic responses is needed when developing adaptations to sea level rise, but national policies currently do not support that local oversight (Hauer et al. 2020). In addition to the difficulties created by pursuing a top-down approach, the policies themselves have tended to have a disproportionate focus on physical and resource management of the coastline rather than adaptations that address the social and human impacts of climate change (Clarke et al. 2013; Butler et al. 2015; Cinner and Barnes 2019). The physical effects of climate change have been prioritized over livelihood, well-being, and cultural needs of communities. Such an approach requires reconciling lagoon conservation issues with the livelihood interests and local economy of lagoon communities. In Ghana, an example of the disconnect between national coastal resource policy and local community needs is seen in the mismanagement of mangroves. Mangroves are overexploited by lagoon communities, despite playing a vital role in the physical protection of coastal areas, and mangrove conservation plans at lagoons have suffered from a lack of administrative coordination across ministries and agencies (Boateng 2018). Conventional multi- 
institutional, top-down systems of government have not been very successful in resolving or managing coastal problems (Clarke et al. 2013). The need to shift to a human-centered, bottom-up approach to managing lagoon environments and their communities, where communities are participants to the planning, co-production, and implementation of coastal adaptations to climate change, is key to their longterm resilience and sustainability (Butler et al. 2015).

\section{Participatory Governance}

The recognition of the gap between national policy discourse and local implementation has prompted a shift to the development of a more participatory approach that ensures coastal communities are central to the joint management of their resources and local environment. In this participatory approach, community knowledge is used to bridge the gap between national policy, climate research, and lived experience of climate change (Clarke et al. 2013). The resultant integrated governance systems to support climate change planning and adaptations combine local participatory governance with multi-institutional government and nongovernmental organizations. This bottom-up approach ensures that community needs are addressed and local conditions are taken into account in adaptations to climate change and the management strategies that support them. In effect, a balance between "top-down" policy implementation and "bottom-up" community-driven needs that maps the top-down agenda to a community-based approach is recommended for successful adaptive strategies (Butler et al. 2015). In this approach, there is a recognition of the contextual factors through local stakeholder engagement as well as the integration of indigenous knowledge and local approaches to understand, manage, and create solutions for climate change adaptations (Cinner and Barnes 2019). Indigenous knowledge and traditional practices have developed over generations by communities coping with climatic variability and extreme weather (FAO 2018), such as in Nigeria, where SSF communities use their traditional knowledge of local meteorological variation to inform adaptations to the management of coastal flooding.

Most of the research about participatory governance of coastlines in West Africa focuses on Ghana and Nigeria with fewer studies from Benin, Togo, and Cote d'Ivoire. Ghana has many agencies with a top-down institutional framework, including those that govern the coastal and marine environment. However, progress is being made toward creating participatory structures for coastal management and climate change adaptation, specifically around the areas of resource management, environmental monitoring, and community education (Wiafe et al. 2013). The participatory approach is also being used in fishing communities along the Badagry coast of Nigeria to create and implement local adaptations to climate and environmental change (Olawepo 2008). Another example is from the Aby Lagoon in Côte d'Ivoire, where co-management of fishing resources has given fishing communities a sense of engagement, ownership, and empowerment that has supported sustainable livelihoods, enhancing resilience to climate change (Njifonjou et al. 2006). The 
success of these participatory approaches is encouraging for future implementation of climate change adaptations in coastal lagoon communities across West Africa.

\section{Summary}

The coastlines of Cote d'Ivoire, Ghana, Benin, Togo, and Nigeria are dominated by dynamic lagoon environments. Sea level rise and climatic changes are affecting those lagoons and their associated nearshore environments. The fishing communities that live next to lagoons depend on them for resources and ecosystem services that support economic livelihood and well-being. The vulnerability of lagoon communities to climate change is related not only to the physical and environmental effects of climate change but also to local resource use, sociocultural community structures, susceptibility to external factors, population growth, and governance infrastructures. The interconnected nature of climate-related challenges with development issues complicates the success of climate change adaptations and interventions. Adaptations enacted as part of a managed intervention plan require an understanding that vulnerability to climate change is not felt in the same way in different communities nor even across a single community and an acknowledgment of intersectionality is required when deciding how and where to place adaptation interventions.

Multiple frameworks exist in West Africa that are related to the management of the coastal zone, and National Adaptation Programme of Action (NAPA) plans in the region have included coastal communities. National coastal policy arising from such frameworks should be the vehicle for managing climate change adaptations in lagoon communities. However, where such policy exists, it has suffered from formal top-down approaches with gaps between policy and its implementation as well as uncoordinated approaches. Importantly, the policies themselves have failed to acknowledge the human experience of climate change, tending to focus on physical change at the coast. To rectify this, climate and coastal change policy must evolve to embed concepts of adaptation and adaptive capacity, giving the same consideration to community livelihood and well-being as to the physical environment. An integrated participatory approach, which allows lagoon communities to play a key role in the governance of the coastal zone, will enable such a human-centric approach and facilitate the integration of climate change adaptation into coastal planning and management.

\section{References}

Adelekan IO (2010) Vulnerability of poor urban coastal communities to flooding in Lagos, Nigeria. Environ Urban 22(2):433-450. https://doi.org/10.1177/0956247810380141

Adeniyi MO (2016) The consequences of the IPCC AR5 RCPs 4.5 and 8.5 climate change scenarios on precipitation in West Africa. Clim Chang 139:245-263. https://doi.org/10.1007/ s10584-016-17774-2

Adelekan I, Fregene T (2015) Vulnerability of artisanal fishing communities to flood risks in coastal southwest Nigeria. Clim Dev 7(4):322-338. https://doi.org/10.1080/17565529.2014.951011 
Adjei JK, Sika-Bright S (2019) Traditional beliefs and sea fishing in selected coastal communities in the Western Region of Ghana. Ghana J Geogr 11(1):1-19. https://doi.org/10.4314/gjg.v11i1.1

Agrawal A (2008) The role of local institutions in adaptation to climate change. World Bank. https:// doi.org/10.1596/28274

Akanni KA (2010) Fishing technologies and catch levels among small-scale fishers in Lagos state, Nigeria. N Am J Fish Manag 30:309-315. https://doi.org/10.1577/M08-061.1

Anthony EJ, Oyede LM, Lang J (2002) Sedimentation in a fluvially infilling, barrier-bound estuary on a wave-dominated, microtidal coast: the Ouémé River estuary, Benin, west Africa. Sedimentology 2002 49(5):1095-1112. https://doi.org/10.1046/j.1365-3091.2002.00491.x

Appeaning-Addo K (2014) Managing shoreline change under increasing sea-level rise in Ghana. Coast Manag 42:555-567. https://doi.org/10.1080/08920753.964820

Atti-Mama C (1998) Co-management in continental fishing in Benin: the case of lake Nokoué. In The International Workshop on Fisheries Co-Management. (NO DOI)

Awoskia LF, Ibe AC (1993) Geomorphology and tourism related aspects of the Lekki barrier-lagoon coastline in Nigeria. In: Wong PP (ed) Tourism vs environment: the case for coastal areas. The geo-journal library v. 26. Springer, Dordrecht. https://doi.org/10.1007/978-94-011-2068-5_9

Béné C (2006) Small-scale fisheries: assessing their contribution to rural livelihoods in developing countries. FAO Fish Circ 1008:46. (NO DOI)

Bernacsek GM, Hughes JS, Hughes RH (1990) A directory of African wetlands. (NO DOI)

Blankespoor B, Dasgupta S, Laplant B (2014) Sea level rise and coastal wetlands, Ambio. The Royal Swedish Academy of Sciences. https://doi.org/10.1007/s13280-014-0500-4

Boateng I (2012) An application of GIS and coastal geomorphology for large scale assessment of coastal erosion and management: a case study of Ghana. Journal of coastal conservation 16 (3):383-397. https://doi.org/10.1007/s11852-012-0209-0

Boateng I (2018) An assessment of vulnerability and adaptation of coastal mangroves of West Africa in the face of climate change. In: Makowski C, Finki CW (eds) Threats to mangrove forests, coastal research library 25. https://doi.org/10.1007/978-3-319-73016.5_7

Brown S, Kebede AS, Nicholls RJ (2011) Sea level rise and impacts in Africa 2000-2010. http:// www.unep.org/climatechange/adaptation/Portals/133/documents. (NO DOI)

Butler JRA, Wise RM, Skewes TD, Bohensky EL, Peterson N, Suadnya W, Yanuartati Y, Handayani T, Habibi P, Puspadi K, Bou N, Vaghelo D, Rochester W (2015) Integrating topdown and bottom-up adaptation planning to build adaptive capacity: a structured learning approach. Coast Manag 43:346-364. https://doi.org/10.1080/08920753.2015.1046802

Cinner JE, Barnes ML (2019) Social dimensions of resilience in social-ecological systems. One Earth 1:51-56. https://doi.org/10.1016/j.oneear.2019.08.003

Chambers R, Conway G (1992) Sustainable rural livelihoods: practical concepts for the 21st century. Institute of Development Studies (UK). https://opendocs.ids.ac.uk/opendocs/handle/ 20.500.12413/775

Clarke B, Stocker L, Coffey B, Leith P, Harvey N, Baldwin C, Baxter T, Bruekers G, Galano CD, Good M, Haward M, Hofmeester C, De Freitas DM, Mumford T, Nursey-Bray M, Kriwoken L, Shaw J, Shaw J, Smith T, Thomsen D, Wood D, Cannard T (2013) Enhancing the knowledgegovernance interface: coasts, climate and collaboration. Ocean Coast Manag 86:88-99. https:// doi.org/10.1016/j.ocecoaman.2013.02.009

Danladi IB, Kore BM, Gul M (2017) Vulnerability of the Nigerian coast: an insight into sea level rise owing to climate change and anthropogenic activities. J Afr Earth Sci. https://doi.org/10. 1016/j.jafrearsci.2017.07.019

Davies-Vollum KS, West M (2015) Shoreline change and sea level rise at the Muni-Pomadze coastal wetlands (Ramsar site), Ghana. J Coast Conser Manage 19(4):515-525. https://doi.org/ 10.1007/s11852-015-0403-y

Daudu AK, Oladipo FO, Olatinwo LK, Kareem WO (2020) Analysis of factors influencing vulnerability of fishing systems to climate change among Artisanal Fisher-folks in Coastal area of Lagos, Nigeria. Afr J Land Policy Geospat Sci 3(1):80-98. Retrieved from https:// revues.imist.ma/index.php/AJLP-GS/article/view/17924 (No DOI) 
Dey MM, Gosh K, Valmonte-Santos R, Rosegrant MW, Chen OL (2016) Economic impact of climate change and climate change adaptation strategies for fisheries sector in Fiji. Mar Policy 67:164-170. https://doi.org/10.1016/j.marpol.2015.12.023

Djihouessi BD, Djihouessi MB, Aina MP (2016) A review of habitat and diversity research in Lake Nokue, Benin Republic: current state of knowledge and prospects for future research. Ecohydrol Hydrobiol 19:131-145. https://doi.org/10.1016/j.ecohyd.2018.04.003

Diop S, Sherin PA (2016) Sustainable oceans and coasts: lessons learnt from eastern and Western Africa. Estuar Coast Shelf Sci 18:327-339. https://doi.org/10.1016/j.ecss.2016.03.032

Dossou KM, Glehouenou-Dossou B (2007) The vulnerability to climate change of Cotonou (Benin) the rise in sea level. Environ Urban 19(1):65-79. https://doi.org/10.1007/978-94-007-7088-1_25

Druyan L (2011) Review: studies of 21-century precipitation trends over West Africa. Int J Climatol 31:1415-1424. https://doi.org/10.1002/joc.2180

Duck RW, de Silva JF (2012) Coastal lagoons and their evolution. Estuar Coastal Shelf Sci 110:214. https://doi.org/10.1016/j.ecss.2012.03.00

Evadzi PIK, Scheffran J, Zurita E, Hunicke B (2018) Awareness of sea-level response under climate change on the coast of Ghana. J Coast Conserv 22:183-197. https://doi.org/10.1007/s11852017-0569-6

FAO (2018) The state of world fisheries and aquaculture 2018 - meeting the sustainable development goals. FAO. (No DOI)

Freduah G, Fidelman P, Smith TF (2018) Mobilising adaptive capacity to multiple stressors: insights from small-scale coastal fisheries in the Western Region of Ghana. Geoforum 91:6172. https://doi.org/10.1016/j.geoforum.2018.02.026

GCLME (2006) Guinea current large marine ecosystem (GCLME)- transboundary diagnostic analysis: a programme of the governments of the GCLME countries under GEF/UNIDO/ UNDP/UNEP/US-NOAA/NEPAD/FAO and IMO. (No DOI)

GEF (1992) Coastal Wetlands Management Project, Republic of Ghana. Global Environment Facility. Project document, August 1992. World Bank. (No DOI)

Ghana Embassy (2014) Population. http://www.ghanaembassy.org/index.php?page=population. (No DOI)

Hastings RA, Rutterford LA, Freer JJ, Collins RA, Simpson SD, Genner MJ (2020) Climate change drives poleward increases and equatorward declines in marine species. Current Biology 30(8): 1572-1577.e2

Hauer ME, Fussell E, Mueller V et al (2019) Sea level rise and human migration. Nat Rev Earth Environ 1:28-39. https://doi.org/10.1038/s43017-019-0002-9

IPCC (2014) In: Barros VR, Field CB, Dokken DJ, Mastrandrea MD, Mach KJ, Bilir TE, Chatterjee M, Ebi KL, Estrada YO, Genova RC, Girma B, Kissel ES, Levy AN, MacCracken S, Mastrandrea PR, White LL (eds) Climate change 2014: impacts, adaptation, and vulnerability. Part B: regional aspects. Contribution of working group II to the fifth assessment report of the intergovernmental panel on climate change. Cambridge University Press, Cambridge, UK/New York, p 688. (No DOI)

Koomson D, Davies-Vollum KS, Raha D (2020) Characterising the vulnerability of fishing households to climate and environmental change: insights from Ghana. Mar Policy 120 (2020):104142. https://doi.org/10.1016/j.marpol.2020.104142

Lam VW, Cheung WW, Reygondeau G, Sumaila UR (2016) Projected change in global fisheries revenues under climate change. Sci Rep 6:32607. https://doi.org/10.1038/srep32607

Mauerhofer V, Kim RE, Stevens C (2015) When implementation works: a comparison of Ramsar convention implementation in different continents. Environ Sci Pol 51:95-105. https://doi.org/ 10.1016/j.envsci.2015.03.016

Njifonjou O, Satia B, Angaman K (2006) Fisheries co-management and poverty alleviation in the context of the sustainable livelihoods approach: a case study in the fishing communities of aby lagoon in cote d'Ivoire. Int J Sustain Dev World Ecol 13(6):448-458. (No DOI)

Niyonkuru C, Lalèyè PA (2010) Impact of acadja fisheries on fish assemblages in Lake Nokoué, Benin, West Africa. Knowl Manag Aquat Ecosyst 399:05. https://doi.org/10.1051/kmae/ 2010033 
Ochiewo J (2004) Changing fisheries practices and their socioeconomic implications in south coast Kenya. Ocean Coast Manag 47(7):389-408. https://doi.org/10.1016/j.oceceoaman.2004.07.006

Odunga S, Badru G, Olalekan MB (2014) Climate change, sea level rise and coastal inundation along part of Nigeria barrier lagoon coast. J Appl Sci Environ Manage 18(1):41-47. https://doi. org/10.4314/jasem.v18i1.6

Olawepo RA (2008) Using participatory rural appraisal to explore coastal fishing in Badagry villages, Nigeria. Environmentalist 28:108-122. https://doi.org/10.1007/s10669-007-9052-5

Perry RI, Sumaila UR (2007) Marine ecosystem variability and human community responses: the example of Ghana, West Africa. Mar Policy 31(2):125-134. https://doi.org/10.1016/j.marpol. 2006.05.011

Rahmstorf S (2007) A semi-empirical approach to projecting Future Sea-level rise. Science 315:368-370. https://doi.org/10.1126/science.1135456

Sagoe-Addy K, Appeaning Addo K (2013) Effect of predicted seal level rise on tourism facilities along Ghana's coast. J Coast Conserv 17:155-166. https://doi.org/10.1007/s11852-012-0227-y

Scoones I (1998) Sustainable rural livelihoods: a framework for analysis. IDS working paper 72. https://opendocs.ids.ac.uk/opendocs/handle/20.500.12413/3390

Short R, Gurung R, Rowcliffe M, Hill N, Milner-Gulland EJ (2018) The use of mosquito nets in fisheries: a global perspective. PLoS One 13(1):e0191519. https://doi.org/10.1371/journal.pone. 0191519

USAID (2014) Sustainable wetlands adaptation and mitigation programme: final report. https:// www.cifor.org/fileadmin/subsites/twincam/reports/SWAMP_Final_Report_2014.pdf. (No DOI)

UN (2015) Transforming our world, The 2030 Agenda for Sustainable Development. https:// sustainabledevelopment.un.org/post2015/transformingourworld/publication. (No DOI)

Wiafe G (2010) Coastal and continental shelf processes in Ghana. NTIS technical report. University of Ghana, Accra. http://www.onr.navy.mil/reports/FY11/lowaife.pdf. (No DOI)

Wiafe G, Boateng I, Appeaning-Addo K (2013) Handbook for coastal processes and management in Ghana. Gloucester: Choir Press, $274 \mathrm{p}$.

World Bank (2019) West Africa’s coast: losing over £3.8 Billion a year to erosion, flooding and pollution. https://www.worldbank.org/en/region/afr/publication/west-africas-coast-losing-over38-billion-a-year-to-erosion-flooding-and-pollution. (No DOI)

World Bank Group (2015) Economic, environmental, and social evaluation of Africa's small-scale fisheries environment and natural resources global practice policy note

Zacarias DA (2019) Understanding community vulnerability to climate change and variability at a coastal municipality in southern Mozambique. Int J Climate Change Strateg Manage 11(1):154 176. https://doi.org/10.1108/IJCCSM-07-2017-0145

Open Access This chapter is licensed under the terms of the Creative Commons Attribution 4.0 International License (http://creativecommons.org/licenses/by/4.0/), which permits use, sharing, adaptation, distribution and reproduction in any medium or format, as long as you give appropriate credit to the original author(s) and the source, provide a link to the Creative Commons license and indicate if changes were made.

The images or other third party material in this chapter are included in the chapter's Creative Commons license, unless indicated otherwise in a credit line to the material. If material is not included in the chapter's Creative Commons license and your intended use is not permitted by statutory regulation or exceeds the permitted use, you will need to obtain permission directly from the copyright holder.

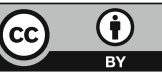

